\title{
Metabolism of Tryptophan by Pseudomonas aureofaciens and Its Relationship to Pyrrolnitrin Biosynthesis
}

\author{
By OLGA SALCHER AND FRANZ LINGENS* \\ Institute of Microbiology, University of Hohenheim, Garbenstrasse 30, \\ $D-7000$ Stuttgart 70, Federal Republic of Germany
}

(Received 29 February 1980; revised 21 May 1980)

\begin{abstract}
Studies on the metabolism of tryptophan in Pseudomonas aureofaciens ATCC 15926 revealed different metabolic routes for the $\mathrm{L}$ - and $\mathrm{D}$-isomer besides the biosynthetic pathway for pyrrolnitrin synthesis. L-Tryptophan catabolism follows the aromatic route via anthranilic acid. Tryptophan 2,3-dioxygenase was induced by L-tryptophan. Kynureninase and anthranilate 1,2-dioxygenase were induced by L-tryptophan, L-kynurenine and anthranilic acid. Anthranilate 1,2-dioxygenase was absent from a mutant strain of $P$. aureofaciens ATCC 15926 which produced about 30-fold increased amounts of pyrrolnitrin. The $K_{\mathrm{m}}$ values of tryptophan 2,3-dioxygenase and kynureninase did not differ substantially between the two strains. Kynurenine 3-monooxygenase, 3-hydroxyanthranilate 3,4-dioxygenase, tryptophanase and indolyl-3-alkane $\alpha$-hydroxylase activities were not detected. D- and L-tryptophan were converted to indole-3-pyruvate by tryptophan aminotransferase and via indole-3-acetaldehyde to indole-3-acetic acid. This additional catabolic pathway as well as tryptophan racemase activity was constitutive and present in both strains.
\end{abstract}

\section{INTRODUCTION}

Tryptophan is the precursor of the antifungal agent pyrrolnitrin (Floss et al., 1971; see Fig. 1) which is produced by several pseudomonads (Arima et al., 1964; Elander et al., 1968). Pyrrolnitrin, aminopyrrolnitrin and 3-chloroindole were isolated from cultures of Pseudomonas aureofaciens ATCC 15926 (Lively et al., 1966).

During our studies on pyrrolnitrin biosynthesis, 4-(2-amino-3-chlorophenyl)pyrrole2-carboxylic acid, 7-chloroindole-3-acetic acid, 3-chloroanthranilic acid, indole-3-acetic acid and anthranilic acid were identified in cultures of $P$. aureofaciens (Salcher et al., 1980). The formation of these metabolites depended on the growth conditions (e.g. supplementation with D- or L-tryptophan). 4-(2-Amino-3-chlorophenyl)pyrrole-2-carboxylic acid was isolated from cultures grown in glycerol minimal medium containing $3 \mathrm{~mm}$-D-tryptophan, whereas the enzyme activity for the formation of indole-3-acetamide or 7-chloroindole3 -acetamide was only present in cultures grown in glycerol minimal medium without any supplements. These results led us to question to what extent the pathways of tryptophan catabolism and pyrrolnitrin biosynthesis might compete for the same precursor, and how the D- or L-isomer of tryptophan would be metabolized. Furthermore, it was of interest to compare the enzyme pattern of tryptophan metabolism of the parent strain $P$. aureofaciens ATCC 15926 with the mutantstrain ACN, which was obtained by mutagenesis with $N$-methyl$N^{\prime}$-nitro- $N$-nitrosoguanidine (Salcher \& Lingens, 1980). This mutant strain produced about 30 -fold increased amounts of pyrrolnitrin in a defined medium. Whereas the wild-type used L-tryptophan and anthranilic acid as sole sources of carbon, the mutant showed delayed 


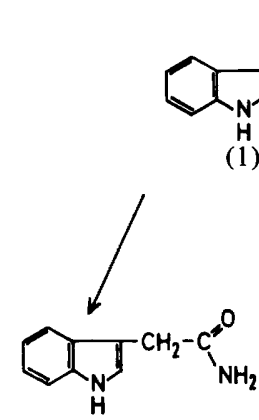

(5)
(1)

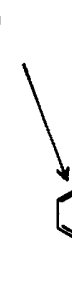

$\mathrm{H}_{2} \mathrm{COOH}$

H

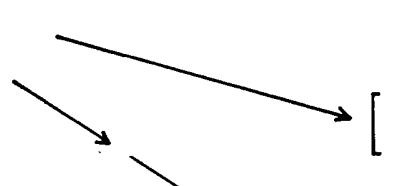<smiles>CC1=CC=C2Cc3cccc(c31)N2</smiles>

(6)

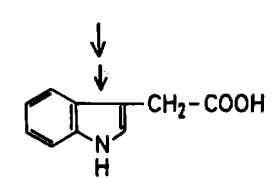

(7)<smiles>NC(CC(=O)CC1CC2C[C@H]1CCC2N)C(=O)O</smiles>

(8)

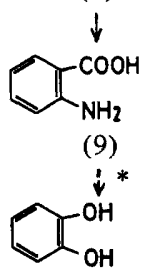

(10)

$(11)+(12)$

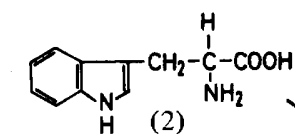

(3)

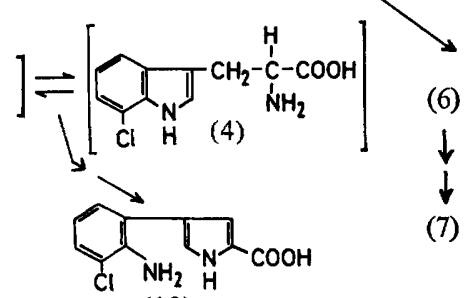
(13)<smiles>Cc1ccc(Cl)c(N)c1-c1cc(Cl)c(C(=O)O)[nH]1</smiles>

(14)

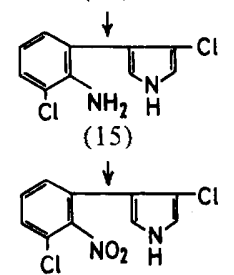

(16)

Fig. 1. Tryptophan metabolism in Pseudomonas aureofaciens wild-type ATCC 15926 and mutant ACN. The reaction catalysed by anthranilate 1,2-dioxygenase, which is absent from the mutant strain, is indicated by an asterisk. Trivial names of compounds: L-tryptophan (1), D-tryptophan (2), 7-chloro-L-tryptophan (3), 7-chloro-D-tryptophan (4), indole-3-acetamide (5), indole-3-pyruvic acid (6), indole-3-acetic acid (7), L-kynurenine (8), anthranilic acid (9), catechol (10), acetate (11), succinate (12), 4-(2-amino-3-chlorophenyl)pyrrole-2-carboxylic acid (13), 3-chloro-4-(2-amino3-chlorophenyl)pyrrole-2-carboxylic acid (14), aminopyrrolnitrin (15), pyrrolnitrin (16).

growth with L-tryptophan and none with anthranilic acid (Salcher \& Lingens, 1980). Our studies were therefore aimed also at the question of how increased production of secondary metabolites may be explained.

\section{METHODS}

Strains and growth conditions. Pseudomonas aureofaciens wild-type ATCC 15926 and mutant ACN were grown in a defined medium as described by Blumenstock et al. (1980). Carbon sources other than glycerol were sterilized by filtration and added at a final concentration of $3 \mathrm{~mm}$.

Bacteria were grown at $30^{\circ} \mathrm{C}$ with rotary shaking $\left(100 \mathrm{rev} . \mathrm{min}^{-1}\right)$ in 21 Erlenmeyer flasks containing $500 \mathrm{ml}$ medium. The cultures were inoculated with $5 \mathrm{ml}$ of a cell suspension taken from the exponential growth phase (approx. $1 \times 10^{8}$ cells $\mathrm{ml}^{-1}$ ) and resuspended in $0.05 \mathrm{M}-\mathrm{K} / \mathrm{Na}$-phosphate buffer, $\mathrm{pH} 7 \cdot 0$. The bacteria were harvested in the late-exponential growth phase at a density corresponding to $2.5 \times 10^{9}$ viable cells $\mathrm{ml}^{-1}$ or an $A_{400-600}$ of 1.5 in the Eppendorf photometer. The cells were washed twice with $0.05 \mathrm{M}-\mathrm{K} / \mathrm{Na}-$ phosphate buffer, $\mathrm{pH} 7 \cdot 0$, and stored at $-18^{\circ} \mathrm{C}$.

Pseudomonas fluorescens ATCC 29574, the reference strain for the indolyl-3-alkane $\alpha$-hydroxylase test, was grown by the method of Roberts \& Rosenfeld (1977) as well as under the cenditions described above.

Preparation of cell extracts. Cells were disrupted by grinding with aluminium oxide (Blumenstock et al., 1980) or by ultrasonication (Branson-Sonifier; $50 \mathrm{~W}, 6 \times 30 \mathrm{~s}$ ). For the latter method $1 \mathrm{~g}$ of frozen cells was suspended in $3 \mathrm{ml} 0.05 \mathrm{~mm}-\mathrm{K} / \mathrm{Na}$-phosphate buffer, $\mathrm{pH} 7.0$. After disruption and subsequent centrifugation at $30000 \mathrm{~g}\left(4^{\circ} \mathrm{C}\right)$, the supernatant was dialysed against $100 \mathrm{vol} .0 .05 \mathrm{mM}-\mathrm{K} / \mathrm{Na}$-phosphate buffer,

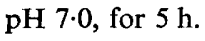

Protein determinition. Protein concentration was determined by the methods of Layne (1957) and Lowry. 
Enzyme assays. Anthranilate 1,2-dioxygenase (EC 1.14.12.1) was measured by the decrease in absorption at $310 \mathrm{~nm}$ due to the disappearance of the substrate anthranilate (Kobayashi \& Hayaishi, 1970). The enzyme activity was lost after freezing the extracts.

3-Hydroxyanthranilate 3,4-dioxygenase (EC 1.13.11.6) was assayed by measuring the increase in absorption at $360 \mathrm{~nm}$ due to the production of 2-amino-3-carboxymuconate semialdehyde (Nishizuka et al., 1970).

Activities of indole-3-acetaldehyde dehydrogenase and indole-3-pyruvate decarboxylase were determined according to the method of Fujioka et al. (1970).

Kynurenine 3-monooxygenase (EC 1.14.13.9) was assayed spectrophotometrically by measuring the decrease in absorption at $340 \mathrm{~nm}$ due to the oxidation of NADPH (Okamoto, 1970).

Kynureninase (EC 3.7.1.3) activity was measured spectrophotometrically by the decrease in absorbance at $365 \mathrm{~nm}$ (Knox, 1955).

Tryptophan 2,3-dioxygenase (EC 1.13.11.11) was assayed according to Ishimura (1970). The formylkynurenine formed was converted to kynurenine by the formamidase present in crude extracts and determined by the zinc acetate method (Yamamoto \& Hayaishi, 1970). The interfering kynureninase activity in crude extracts was eliminated by preincubation with $5 \mathrm{~mm}$-semicarbazide (Palleroni \& Stanier, 1964).

Tryptophanase (EC 4.1 .99 .1 ) activity was measured by colorimetric deternination of the indole formed (Morino \& Snell, 1970).

Indolyl-3-alkane $\alpha$-hydroxylase was assayed by the method of Narumiya et al. (1979).

The purity of the D- and L-tryptophan used was tested polarographically with L-amino acid oxidase (EC 1 4.3.2) and D-amino acid oxidase (EC 1.4.3.3) according to the method of Wellner (1971) or Yagi (1971).

Tryptophan racemase was tested according to Behrman (1962) and tryptophan aminotransferase (EC 2.6.1.27) by the method of Fujioka et al. (1970).

Thin-layer chromatography. The production of metabolites during growth and during the enzyme reactions was also followed by thin-layer chromatography (Salcher \& Lingens, 1980).

Determination of extracellular L-tryptophan. The production of extracellular L-tryptophan was analysed (Snell, 1957) in minimal medium containing 3 mm-D-tryptophan. Samples $(10 \mathrm{ml})$ were taken from the cultures during growth and centrifuged at $5000 \mathrm{~g}$. The supernatants were sterilized by filtration and assayed microbiologically using Lactobacill s arabinosus ATCC 8014 as the test organism.

Reagents. These were of the highest purity grade available. L-Tryptophan and anthranilic acid were obtained from Merck. D-Tryptophan, 3-hydroxyanthranilic acid, L-3-hydroxykynurenine, L-kynurenine sulphate, indole-3-acetic acid and the remaining indole compounds were obtained frcm Sigma. L-Amino acid oxidase (snake venom) and D-amino acid oxidase (hog kidney) were purchased from Boehringer.

\section{RESULTS AND DISCUSSION}

\section{The aromatic pathway of tryptophan catabolism}

Kynurenine is a branchpoint metabolite of tryptophan catabolism in pseudomonads since two alternative routes diverge from it: the aromatic pathway via anthranilic acid and the quinoline pathway via kynurenic acid (Behrman, 1962). Pseudomonas aureofaciens ATCC 15926 was unable to use D-tryptophan and kynurenic acid as sole carbon sources, whereas anthranilic acid was metabolized (Salcher \& Lingens, 1980). Tryptophan catabolism through L-kynurenine in $P$. aureofaciens follows the aromatic pathway via anthranilic acid (Fig. 1). Tryptophan 2,3-dioxygenase, the first enzyme of this pathway, is induced by L-tryptophan but not by L-kynurenine (Table 1). This is in contrast to the situation in $P$. fluorescens where the latter compound induces tryptophan 2,3-dioxygenase (Palleroni \& Stanier, 1964).

In the following studies the effect of D-tryptophan and of glycerol on the induction of catabolic enzyme synthesis was examined. The cultures were grown in the presence of 3 mM-D-tryptophan together with $3 \mathrm{~mm}$-glycerol, because $P$. aureofaciens was unable to use D-tryptophan as sole carbon source. The same culture conditions were applied in other growth studies with L-tryptophan, L-kynurenine and anthranilic acid, each at $3 \mathrm{~mm}$. Catabolic enzyme activities of bacteria grown in the presence of $3 \mathrm{~mm}-\mathrm{D}$-tryptophan were within the range characteristic of uninduced bacteria (Table 1). Tryptophan 2,3-dioxygenase, kynureninase and anthranilate 1,2-dioxygenase were induced by L-tryptophan in the presence 
Table 1. Induction of enzymes of the aromatic pathway of tryptophan catabolism in Pseudomonas aureofaciens wild-type ATCC 15926 and mutant ACN

Enzyme activities were determined as described in Methods and are expressed as $\mu \mathrm{mol} \mathrm{min}^{-1}$ $(\mathrm{mg} \text { protein })^{-1}$.

\begin{tabular}{|c|c|c|c|c|}
\hline \multirow[b]{2}{*}{ Strain } & \multirow[b]{2}{*}{$\begin{array}{l}\text { Carbon source added to } \\
\text { minimal medium ( } 3 \mathrm{~mm})\end{array}$} & \multicolumn{3}{|c|}{ Enzyme activity } \\
\hline & & $\begin{array}{l}\text { Tryptophan } \\
\text { 2,3-dioxygenase }\end{array}$ & Kynureninase & $\begin{array}{c}\text { Anthranilate } \\
\text { 1,2-dioxygenase }\end{array}$ \\
\hline Wild-type ATCC 15926 & $\begin{array}{l}\text { Anthranilic acid } \\
\text { Glycerol } \\
\text { L-Kynurenine } \\
\text { D-Tryptophan + glycerol } \\
\text { L-Tryptophan }\end{array}$ & $\begin{array}{l}0.02 \\
0.09 \\
0.08 \\
0.08 \\
3 \cdot 1\end{array}$ & $\begin{array}{l}4 \cdot 3 \\
0 \cdot 9 \\
8 \cdot 2 \\
1 \cdot 2 \\
8 \cdot 5\end{array}$ & $\begin{array}{l}3 \cdot 2 \\
0.83 \\
6 \cdot 8 \\
0.95 \\
7 \cdot 2\end{array}$ \\
\hline Mutant ACN & $\begin{array}{l}\text { Anthranilic acid } \\
\text { Glycerol } \\
\text { L-Kynurenine } \\
\text { D-Tryptophan + glycerol } \\
\text { L-Tryptophan }\end{array}$ & $\begin{array}{l}0.03 \\
0.03 \\
0.07 \\
0.09 \\
2.9\end{array}$ & $\begin{array}{l}2 \cdot 2 \\
0 \cdot 7 \\
5 \cdot 1 \\
0 \cdot 5 \\
4 \cdot 7\end{array}$ & $\begin{array}{l}0 \\
0 \\
0 \\
0 \\
0\end{array}$ \\
\hline
\end{tabular}

Table 2. Comparison of the $K_{\mathrm{m}}$ values of anthranilate 1,2-dioxygenase, kynureninase and tryptophan 2,3-dioxygenase from Pseudomonas aureofaciens wild-type ATCC 15926 and mutant ACN

Enzyme activities were assayed as described in Methods using different substrate concentrations. $K_{\mathrm{m}}$ values were determined from Lineweaver-Burk plots.

\begin{tabular}{lcc} 
Enzyme & \multicolumn{2}{c}{$K_{\mathrm{m}}$ value $(\mu \mathrm{M})$} \\
& $\overbrace{\text { Wild-type ATCC }}$ 15926 & Mutant ACN \\
Anthranilate 1,2-dioxygenase & 120 & No activity \\
Kynureninase & 250 & 130 \\
Tryptophan 2,3-dioxygenase & 650 & 460
\end{tabular}

of glycerol (results not shown) to the same extent as in its absence (Table 1), indicating that these enzymes were not repressed by glycerol. In contrast to the results obtained with tryptophan 2,3-dioxygenase, the enzymes kynureninase and anthranilate 1,2-dioxygenase were induced by L-kynurenine and anthranilic acid as well as L-tryptophan (Table 1). These results suggest a sequential induction pattern for tryptophan catabolic enzymes in $P$. aureofaciens ATCC 15926 and the mutant strain. Anthranilate 1,2-dioxygenase activity could not be detected in extracts of the mutant strain. Activities (Table 1) and $K_{\mathrm{m}}$ values (Table 2) of tryptophan 2,3-dioxygenase and kynureninase were similar in the two strains.

When L-kynurenine was replaced by L-3-hydroxykynurenine in the kynureninase assay, enzyme activities decreased to $10 \%$. The wild-type strain had an enzyme activity of $0.8 \mu \mathrm{mol}$ $\min ^{-1}$ (mg protein) $)^{-1}$ and the mutant $0.6 \mu \mathrm{mol} \mathrm{min}^{-1}(\mathrm{mg} \text { protein })^{-1}$ when the bacteria were grown in minimal medium containing L-tryptophan as sole carbon source. Similar results for the substrate specificity of kynureninase were obtained with $P$. fluorescens by Gaertner \& Shetty (1977). In $P$. aureofaciens no kynurenine 3-monooxygenase or 3-hydroxyanthranilate 3,4-dioxygenase activity was detected. The route for synthesizing NAD from L-tryptophan is thus not complete. Representatives of the related genus Xanthomonas are known to synthesize NAD from L-tryptophan (Lingens \& Vollprecht, 1964; Lingens et al., 1966) and contain an inducible kynureninase (Shetty \& Gaertner, 1978).

A novel tryptophan-metabolizing enzyme, indolyl-3-alkane $\alpha$-hydroxylase, was isolated from P. fluorescens ATCC 29574 (Roberts \& Rosenfeld, 1977), but neither this enzyme nor tryptophanase could be detected in $P$. aureofaciens. 
Table 3. Influence of L-tryptophan and D-tryptophan on the tryptophan aminotransferase activity in Pseudomonas aureofaciens wild-type ATCC 15926 and mutant ACN

Bacteria were grown in glycerol minimal medium with or without $3 \mathrm{~mm}-\mathrm{L}$ - or D-tryptophan. Tryptophan aminotransferase activity was determined as described in Methods. Activities are expressed as $\mu \mathrm{mol} \mathrm{min}^{-1}$ (mg protein) ${ }^{-1}$.

Supplement to glycerol
minimal medium $(3 \mathrm{~mm})$
D-Tryptophan
L-Tryptophan
None
D-Tryptophan
L-Tryptophan
None

Substrate used in aminotransferase assay

L-Tryptophan

L-Tryptophan

L-Tryptophan

D-Tryptophan

D-Tryptophan

D-Tryptophan
Enzyme activity

$\begin{array}{cc}\text { Wild-type ATCC 15926 } & \text { Mutant ACN } \\ 0.59 & 0.46 \\ 1.2 & 0.84 \\ 0.35 & 0.49 \\ 0.23 & 0.18 \\ 0.22 & 0.21 \\ 0.14 & 0.19\end{array}$

Table 4. Activities of enzymes of the indole-3-acetic acid pathway in Pseudomonas aureofaciens wild-type ATCC 15926 and mutant ACN

Enzyme activities were assayed as described in Methods and are expressed as nmol $\mathrm{min}^{-1}$ $(\mathrm{mg} \text { protein })^{-1}$.

$\begin{array}{clcc}\text { Strain } & \text { Carbon source added to } & \begin{array}{c}\text { Indole- } \\ \text { 3-pyruvate } \\ \text { decarboxylase }\end{array} & \begin{array}{c}\text { Indole- } \\ \text { 3-acetaldehyde } \\ \text { dehydrogenase }\end{array} \\ \text { Wild-type ATCC 15926 } & \text { Glycerol } & 5 \cdot 1 & 8 \cdot 3 \\ & \text { L-Tryptophan } & 6 \cdot 8 & 10 \cdot 4 \\ \text { Dutant ACN } & \text { D-Tryptophan + glycerol } & 7 \cdot 2 & 10 \cdot 0 \\ & \text { Glycerol } & 6 \cdot 5 & 9 \cdot 2 \\ & \text { L-Tryptophan } & 4 \cdot 6 & 7 \cdot 8 \\ & \text { D-Tryptophan +glycerol } & 4 \cdot 3 & 10 \cdot 9\end{array}$

The indole-3-acetic acid pathway

In $P$. aureofaciens a further pathway of tryptophan metabolism is available in synthesizing the phytohormone indole-3-acetic acid, which is also produced by the phytopathogenic species $P$. syringae ( $P$. savastanoi) (Kuo \& Kosuge, 1969). In plants there are several pathways leading from tryptophan to indole-3-acetic acid: the tryptamine pathway, the indole-3-acetaldoxime pathway, the tryptophol pathway and the indole-3-pyruvate pathway (Schneider \& Wightman, 1974). The last pathway is probably present in $P$. aureofaciens (see Fig. 1). Indole-3-pyruvic acid was detected in the tryptophan aminotransferase assay. The enzyme activity was enhanced in extracts of cells grown in the presence of $3 \mathrm{~mm}$ L-tryptophan and when they were assayed with L-tryptophan as substrate (Table 3), whereas the aminotransferase activity with D-tryptophan as substrate was within the range of the activity obtained with L-tryptophan as substrate from cells grown in glycerol minimal medium. In both strains indole-3-pyruvate was metabolized via indole-3-acetaldehyde to indole-3-acetic acid. Indole-3-pyruvate decarboxylase and indole-3-acetaldehyde dehydrogenase (Table 4) as well as tryptophan aminotransferase were constitutive. In neither strain were the activities of L- or D-tryptophan racemase influenced by supplements to the growth medium; the enzyme activities were about $0.3 \mu \mathrm{mol} \mathrm{min}^{-1}$ (mg protein) ${ }^{-1}$ throughout. In order to examine the extent to which the conversion of D-tryptophan to the L-isomer contributed to the extracellular concentration of L-tryptophan, cultures were grown in glycerol minimal medium supplemented with $3 \mathrm{~mm}$-D-tryptophan $\left(612 \mu \mathrm{g} \mathrm{ml}^{-1}\right)$ and the extracellular concentration of L-tryptophan was determined. The maximum concentration, reached in the stationary growth phase, was $0.7 \mu \mathrm{g} \mathrm{L-tryptophan} \mathrm{ml}^{-1}$ for both strains. 
Similar concentrations were detected in cultures grown in glycerol minimal medium without supplements.

\section{Tryptophan catabolism and pyrrolnitrin biosynthesis}

Pyrrolnitrin is synthesized by $P$. chlororaphis, $P$. cepacia ( $P$. multivorans) and several $P$. aureofaciens strains. These organisms produced different amounts of pyrrolnitric when the growth medium (complete medium) was supplemented with D- or L-tryptophan (Elander et al., 1968). The strain-dependent response, which is not a question of the uptake of tryptophan, might be due to different pathways of tryptophan catabolism which compete with the pyrrolnitrin biosynthetic route for the same precursor. Although D-tryptophan enhanced and L-tryptophan depressed pyrrolnitrin production in $P$. aureofaciens, the role of L-tryptophan as a possible precursor should not be excluded, because it may be masked by extensive L-tryptophan catabolism. The mutant strain, which lacks anthranilate 1,2-dioxygenase activity, is more efficient in pyrrolnitrin production.

In cultures of the wild-type and the mutant strain small amounts of 7-chloroindole3-acetic acid and 3-chloroanthranilic acid were detected (Salcher \& Lingens, 1978). The presence of these metabolites suggests the existence of 7-chlorotryptophan. Also 4-(2-amino3-chlorophenyl)pyrrole-2-carboxylic acid, a possible intermediate of pyrrolnitrin biosynthesis, might be derived from 7-chlorotryptophan (Salcher et al., 1978). In addition, the tryptophan 2,3-dioxygenase activity was fivefold lower with 7-chloro-L-tryptophan $\left.\left[0.6 \mu \mathrm{mol} \mathrm{min}^{-1} \text { (mg protein }\right)^{-1}\right]$ instead of L-tryptophan as a substrate (Table 1) when both strains were grown with L-tryptophan as the sole carbon source. These results suggest that pyrrolnitrin biosynthesis and tryptophan catabolism diverge in an early step when 7-chlorotryptophan is produced from tryptophan.

We thank Susanne Weiss for skilful technical assistance, Karl-Heinz van Pée for a sample of 7-chloro-L-tryptophan and the Fonds der Chemischen Industrie for support.

This paper is dedicated to Professor K. Mothes on the occasion of his 80th birthday.

\section{REFERENCES}

Arima, K., Imanaka, H., Kousaka, M., Fukuda, A. \& Tamura, G. (1974). Pyrrolnitrin, a new antibiotic substance, produced by Pseudomonas. Agricultural and Biological Chemistry 28, 575-576.

Behrman, E. J. (1962). Tryptophan metabolism in Pseudomonas. Nature, London 196, 150-152.

Blumenstock, E., Salcher, O. \& Lingens, F. (1980). Regulation of phenylalanine and tyrosine biosynthesis in Pseudomonas aureofaciens ATCC 15926. Journal of General Microbiology 117, 81-87.

Elander, R. P., Mabe, J. A., Hamill, R. H. \& GormaN, M. (1968). Metabolism of tryptophans by Pseudomonas aureofaciens. VI. Production of pyrrolnitrin by selected Pseudomonas species. Applied Microbiology 16, 753-758.

Floss, H. G., ManNi, P. E., Hamill, R. L. \& Mabe, J. A. (1971). Further studies on the biosynthesis of pyrrolnitrin from tryptophan by Pseudomonas. Biochemical and Biophysical Research Communications 45, 781-787.

FujIOKA, M., Morino, Y. \& WADA, H. (1970). Metabolism of phenylalanine (Achromobacter euridice). I. Phenylalanine aminotransferase. II. Phenylpyruvate decarboxylase. III. Phenylacetaldehyde dehydrogenase. Methods in Enzymology 17A, 586-596.
Gaertner, F. H. \& Shetty, A. S. (1977). Kynureninase-type enzymes and the evolution of the aerobic tryptophan to nicotinamide adenine dinucleotide pathway. Biochimica et biophysica acta 482, 453-460.

IsHIMURA, Y. (1970). L-Tryptophan 2,3-dioxygenase (tryptophan pyrrolase) (Pseudomonas fluorescens). Methods in Enzymology 17A, 429-433.

KNOX, W. E. (1955). Tryptophan oxidation. C. Liver and bacterial kynureninases. Methods in Enzymology 2, 249-253.

Kobayashi, S. \& Hayaishi, O. (1970). Anthranilic acid conversion to catechol (Pseudomonas). Methods in Enzymology 17A, 505-510.

KUo, T. T. \& Kosuge, T. (1969). Factors influencing the production and further metabolism of indole3-acetic acid by Pseudomonas savastanoi. Journal of General and Applied Microbiology 15, 51-63.

LAYNE, E. (1957). Spectrophotometric and turbidometric methods for measuring proteins. Methods in Enzymology 3, 447-454.

Lingens, F. \& Vollprecht, P. (1964). Zur Biosynthese der Nicotinsäure in Streptomyceten, Algen, Phycomyceten und Hefe. Hoppe-Seyler's Zeitschrift für physiologische Chemie 339, 64-74. 
Lingens, F., Vollprecht, P. \& GILdemeISTER, V. (1966). Zur Biosynthese der Nicotinsäure in Xanthomonas- und Pseudomonas-Arten, Mycobacterium phlei und Rotalgen. Biochemische Zeitschrift 344, 462-477.

Lively, D., Gorman, M., Haney, M. \& Mabe, J. (1966). Metabolism of tryptophans by Pseudomonas aureofaciens. Biosynthesis of pyrrolnitrin. Antimicrobial Agents and Chemotherapy, 462-469.

Morino, Y. \& SNELl, E. E. (1970). Tryptophanase (Escherichia coli B). Methods in Enzymology 17A, 439-446.

Narumiya, S., TaKaI, K., Tokuyama, T., Noda, Y., Ushiro, H. \& HaYaISHI, O. (1979). A new metabolic pathway of tryptophan initiated by tryptophan side chain oxidase. Journal of Biological Chemistry 254, 7007-7015.

NizhizUKa, Y., IChiYama, A. \& Hayaishi, O. (1970). Metabolism of the benzene ring of tryptophan (mammals). I. 3-Hydroxyanthranilic acid oxygenase (beef liver). Methods in Enzymology 17A, 467-471.

Oкамото, H. (1970). Kynurenine 3-monooxygenase (hydroxylase) (rat liver). Methods in Enzymology 17A, 460-463.

Palleroni, N. J. \& Stanier, R. Y. (1964). Regulatory mechanisms governing synthesis of the enzymes for tryptophan oxidation by Pseudomonas fluorescens. Journal of General Microbiology 35, 319-334.

RoBERTS, J. \& ROSENFELD, H. J. (1977). Isolation, crystallization, and properties of indolyl-3-alkane $\alpha$-hydroxylase. Journal of Biological Chemistry 252, 2640-2647.

SALCHER, O. \& Lingens, F. (1978). Biosynthese von Pyrrolnitrin. Nachweis von 3-Chloranthranilsäure und 7-Chlorindolessigsäure im Kulturmedium von $P_{\text {seudomonas aureofaciens. Tetrahedron Letters }}$ 34, 3101-3102.

SAlCher, O. \& Lingens, F. (1980). Isolation and characterization of a mutant from Pseudomonas aureofaciens ATCC 15926 with an increased capacity for synthesis of pyrrolnitrin. Journal of General Microbiology 118, 509-513.

Salcher, O., Lingens, F. \& Fischer, P. (1978). Biosynthese von Pyrrolnitrin. Nachweis von 4-(2'-Amino-3'-chlorphenyl)pyrrol-2-carbonsäure. Tetrahedron Letters 34, 3097-3100.

Salcher, O., van PÉE, K.-H. \& Lingens, F. (1980). Isolierung von 7-Chlorindol-3-acetamid aus $P_{\text {seudomonas aureofaciens ATCC 15926. Zeitschrift }}$ für Naturforschung 35c, 340-341.

SCHNeIder, E. A. \& Wightman, F. (1974). Metabolism of auxin in higher plants. Annual Review of Plant Physiology 25, 487-513.

Shetty, A. S. \& Gaertner, F. H. (1978). Kynureninase-type enzymes from two strains of Xanthomonas pruni. FEMS Microbiology Letters 3, 259-263.

SNELL, E. E. (1957). Microbiological determination of amino acids. Methods in Enzymology 3, 477492.

Soda, K. \& Osumi, T. (1971). Amino acid racemase (Pseudomonas striata). Methods in Enzymology 17B, 629-630.

WELLNER, D. (1971). L-Amino acid oxidase (snake venom). Methods in Enzymology 17B, 597-600.

YAGr, K. (1971). D-Amino acid oxidase and its complexes (hog kidney). Methods in Enzymology 17B, 608-622.

Yamamoto, S. \& Hayaishi, O. (1970). Tryptophan 2,3-dioxygenase (tryptophan pyrrolase) (rabbit intestine). Methods in Enzymology 17A, 434-438. 